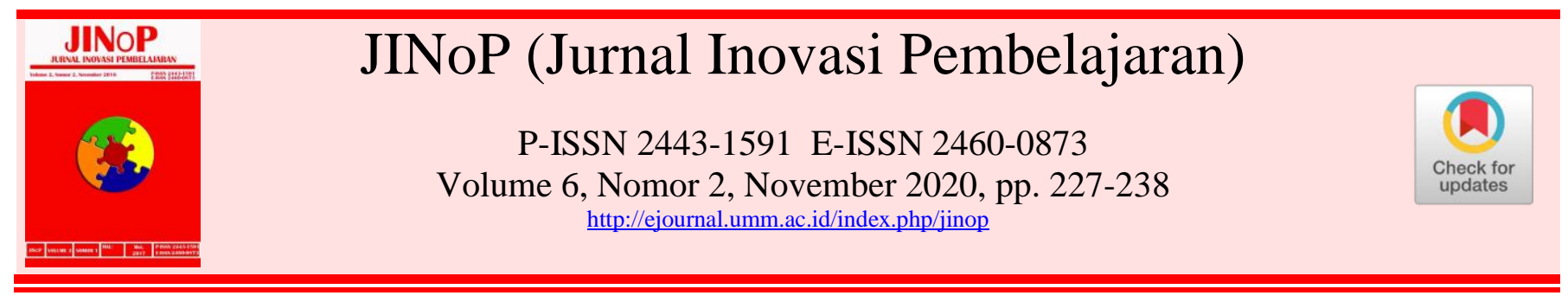

\title{
Penerapan cooperative learning two stay two stray untuk meningkatan hasil belajar dan keaktifan siswa SMA
}

\author{
Dance Bobia Mesah ${ }^{1)^{*}}$, Sri Wahyuni ${ }^{2)}$, Triani Liliek $^{3)}$ \\ ${ }^{1}$ Pendidikan Profesi Guru, Fakultas Keguruan dan Ilmu Pendidikan, Universitas Muhammadiyah \\ Malang, J1. Raya Tlogomas No. 246. Malang, Indonesia \\ ${ }^{2}$ Pendidikan Biologi, Fakultas Keguruan dan Ilmu Pendidikan, Universitas Muhammadiyah \\ Malang, J1. Raya Tlogomas No. 246. Malang, Indonesia \\ ${ }^{3}$ Sekolah Menengah Atas Negeri 8 Malang, Jl. Veteran 37, Malang, Indonesia
}

dance_mesah@yahoo.co.id*; swahyuni48@gmail.com; trianliliek@gmail.com

*Penulis Koresponden

\begin{abstract}
ABSTRAK
Hasil belajar dan keaktifan kelompok siswa pada mata pelajaran Biologi masih tergolong rendah. Hal ini disebabkan pembelajaran belum terpusat pada siswa dan kurang memberikan ruang partisipasi aktif siswa. Penelitian ini bertujuan untuk mendeskripsikan penggunaan TSTS pada pembelajaran Biologi di Kelas XI-IPA. Penelitian ini merupakan Penelitian Tindakan Kelas model Kemmis dan McTaggart, terdiri dari 2 siklus dengan tahapan setiap siklus adalah perencanaan, pelaksanaan tindakan, observasi dan refleksi, materi system peredaran darah. Subjek penelitian adalah siswa berjumlah 32 orang. Teknik pengumpulan data menggunakan obeservasi, tes formatif dan data dianalisis dengan analisis deskriptif kualitatif dan kuantitatif menggunakan persentase. Hasil penelitian menunjukkan bahwa pengguna metode TSTS membuat siswa aktif dalam pembelajaran serta mampu memahami konsep tentang sistem peredaran darah. Peningkatan persentase ketuntasan kelas siklus 1 ke siklus 2 sebesar 25\%, peningkatan persentase rata-rata nilai siswa sebesar $18,12 \%$ dan peningkatan persentase ratarata nilai diskusi kelompok sebesar $10,93 \%$. Kesimpulan penelitian menunjukkan bahwa model Cooperative learning two stay two stray dapat meningkatkan hasil belajar dan keaktifan siswa pada materi sistem sirkulasi darah.

Kata kunci: hasil belajar; keaktifan; two stay two stray.
\end{abstract}

ABSTRACT

The learning outcomes and the activeness of student groups in Biology are considered as low categoriy. The case happened because learning has not been centered on students and does not provide opportunity for student active participation. This research aimed to describe the use of TSTS in Biology learning in Class XI-IPA. This research employed a Classroom Action Research model of Kemmis and McTaggart, consisting of 2 cycles with the stages of each cycle being planning, implementing action, observing and reflecting, and circulatory system material. The research used 32 students as the research subjects and employed data collection techniques by using observation, formative tests. The data were analyzed by using descriptive qualitative and quantitative analysis in percentages. The results showed that the application of the TSTS method resulted in students active in learning and were able to understand the concept of the circulatory system. The increase on the percentage of class completeness was $25 \%$, the average percentage increase of student scores was $18,12 \%$ and the percentage value of the discussion groups was $10.93 \%$. The conclusion of the research shows that the Two Stay Two Stray Cooperative Learning model can improve learning outcomes and student activity in the blood circulation system material.

Keywords: learning outcomes; activeness; two stay two stray. 
diunggah: 2020-08-29, direvisi: 2020-10-26, diterima: 2020-11-20, dipublikasi: 2020-11-20

Copyright (c) 2020 Mesah et al

This is an open access article under the CC-BY license

Cara sitasi: Mesah, D. B., Wahyuni, S., \& Liliek, T. (2021). Penerapan cooperative learning two stay two stray untuk meningkatan hasil belajar dan keaktifan siswa SMA. JINoP (Jurnal Inovasi Pembelajaran), 6(2). 227-238. https://doi.org/10.22219/jinop.v6i2.13461

\section{PENDAHULUAN}

Pendidikan merupakan sebuah kebutuhan dan unsur penting dalam mencerdaskan kehidupan bangsa dan setiap orang berhak memperoleh pendidikan baik secara formal maupun non formal di era global seperti saat ini (Wisarja \& Sudarsana, 2017; Kusumaningrum, Budiyono, \& Subanti, 2015). Karena itu, setiap proses pendidikan seharusnya dikembangkan dan diarahkan untuk menghasilkan sumberdaya manusianya yang berkualitas (Hidayat \& Muhson, 2018). Peningkatan mutu pendidikan perlu adanya perbaikan mutu belajar. Proses belajar mengajar di pendidikan formal adalah serangkaian kegiatan yang terstruktur dan dilakukan secara sadar serta terencana untuk mewujudkan suasana dan proses pembelajaran yang baik agar siswa dapat mengembangkan potensi dirinya. Untuk memperoleh proses pembelajaran yang baik, seorang pendidik perlu menerapkan berbagai model, pendekatan dan atau metode pembelajaran yang tepat dan terpusat pada siswa agar proses pembelajaran dapat berjalan efektif dan efisien untuk meningkatkan hasil belajar (Gayatri, Bahar, \& Handayani, 2017; Rhiantini, Sunarya, \& Iswara, 2017).

Hasil belajar siswa pada kelas XI IPA 5 di SMAN 8 Malang masih kurang aktif dan hasil belajar yang dicapai siswa masih belum baik. Hal ini dilihat dari nilai siswa yang dibawah standar ketuntasan belajar mencapai 60\%. Rendahnya hasil belajar dan keaktifan siswa merupakan dampak berbagai masalah dalam proses pembelajaran. Salah satu permasalahan yang sangat menonjol adalah kurangnya aktifitas siswa dalam proses pembelajaran dimana siswa cenderung pasif dan jenuh karena pembelajaran berorientasi pada keaktifan guru, sehingga konsep materi yang diberikanpun kurang dipahami oleh siswa. Oleh karena itu, guru perlu menciptakan model pembelajaran yang melibatkan kegiatan siswa agar terlibat aktif dan menguasai materi pelajaran untuk memenuhi nilai kriteria ketuntasan belajar yaitu 80 yang wajib dicapai oleh siswa.

Lubis (2018) menyatakan untuk melibatkan siswa aktif dan meningkatkan hasil belajar siswa diperlukan suatu model pembelajaran yang tepat dan salah satunya adalah model pembelajaran kooperatif. Menurut Arthaningsih dan Diputra (2019) model pembelajaran kooperatif memberikan kegiatan pembelajaran kooperatif juga memberikan aktivitas saling mendukung antar siswa dalam diskusi kelompok untuk mengatasi setiap persoalan pembelajaran. Salah satu tipe model pembelajaran kooperatif yaitu Two Stay Two Stray (TSTS). Menurut Sari dan Azmi (2018) dan Paembonan (2019) model pembelajaran kooperatif tipe TSTS ini memberikan pengaruh positif terhadap kemampuan komunikasi yang baik antar peserta didik. Yulianti, Muntari, dan Haris (2015), pembelajaran kooperatif dengan lima prinsip utamanya yang diimplementasikan melalui sintaks tipe two stay two stray dapat memperkuat interaksi positif antara siswa dengan siswa dan dapat mempengaruhi hasil belajar, baik berupa keseriusan, minat belajar, perhatian dan penguasan siswa terhadap materi 
pembelajaran dan metode pembelajaran yang diterapkan. Kegiatan dilakukan dengan cara dua siswa dalam kelompok membagikan informasi kepada anggota kelompok lain yang berkunjung, kemudian dua siswa lainnya mengunjungi kelompok lain untuk memperoleh informasi, sesudah berkunjung, siswa kembali ke kelompok masing-masing untuk membahas hasil informasi diperoleh dari kelompok lain (Huda et al., 2020; Sahela \& Muhammadi, 2020). Keunggulan model pembelajaran kooperatif TSTS menjadikan peserta didik ada motivasi belajar, aktif di dalam kelas, dan ada interaksi sosial antara peserta didik dan belajar dalam kelompok (Habibi \& Rusimamto, 2014; Yusri, Mantasiah, \& Jufri, 2018).

Dari beberapa penelitian diatas belum pernah dilakukan upaya penningkatan hasil belajar dan keaktifan siswa di SMAN 8 Malang kelas XI IPA 5, sehingga penerapan model cooperative learning TSTS sangat penting untuk dilakukan. Penelitian ini bertujuan untuk mendeskripsikan penerapan model Cooperative learning TSTS agar dapat meningkatan hasil belajar siswa pada materi sistem sirkulasi kelas XI IPA 5 SMAN 8 Malang dan untuk menganalisis peningkatan hasil belajar siswa pada materi sistem sirkulasi kelas XI IPA 5 SMAN 8 Malang. Kedepannya hasil penelitian ini dapat digunakan sebagai bahan kajian dasar untuk penerapan model cooperative learning TSTS di mata pelajaran lain pada penelitian yang akan datang.

\section{METODE}

Penelitian ini dilaksanakan di SMA Negeri 8 Malang, subyek dalam penelitian ini yaitu siswa kelas XI IPA 5 yang berjumlah 32 orang dengan kemampuan yang heterogen. Teknik pengumpulan data dalam penelitian ini menggunakan teknik obeservasi. Data pemahaman materi sistem sirkulasi menggunakan tes formatif. Penelitian ini dirancang dengan menggunakan Penelitian Tindakan Kelas (PTK) model Kemmis dan McTaggart dengan menggunakan dua siklus, yaitu:

\section{Siklus I}

\section{Perencanaan Siklus I}

Perencanaan dimulai dengan menyusun RPP dengan materi sistem sirkulasi/komponen darah dan organ peredaran darah. Menyiapkan ringkasan materi yang akan diajarkan yang dituangkan dalam media powerpoint, menyiapkan LKS, video pembelajaran, menyusun soal tes siklus I. Menyiapkan lembar observasi guru dan siswa dalam pelaksanaan pembelajaran disertai format lembar catatan lapangan untuk mengamati situasi ketika pembelajaran sedang berlangsung dan mencatat hal-hal yang belum terekam pada lembar observasi dan menyiapkan lembar observasi penilaian diskusi kelompok

2. Pelaksanaan dan Observasi Siklus I

Pendahuluan dilakukan dengan cara guru memberi salam, absensi dan mengkondisikan kelas. Guru menanyakan kepada siswa materi pertemuan sebelumnya. Guru memotivasi siswa dengan menunjukkan video pembelajaran, kemudian memberi kesempatan kepada siswa untuk memberikan pemahaman tentang gambar/video tersebut. Dilanjutkan dengan guru menyampaikan tujuan pembelajaran, gamabaran umum materi, dan penilaian.

Inti kegiatan dilakukan dengan cara guru membentuk siswa menjadi 8 kelompok yang heterogen dan membagikan LKPD. Guru menjelaskan cara mengerjakan LKPD dan menjelaskan langkah-langkah pembelajaran two stay two 
stray dan menyuruh siswa untuk mencermati persoalan di LKPD sebelum diskusi. Guru membimbing siswa mengumpulkan data dan informasi dalam kelompok dari kajian literatur. Guru membimbing jalannya diskusi dalam menyelesaikan pertanyaan dan membuat media presentasi pada koran bekas. Guru mengarahkan dan membimbing kelompok untuk saling bertamu. Dua orang dari tiap kelompok berkunjung ke kelompok lain dan dua orang menerima tamu dari kelompok lain untuk bertukar informasi, setelah itu masing-masing kembali ke kelompok dan membagikan hasil temuan mereka kepada kelompok asalnya dan membahas hasil kerja mereka (menerapkan two stay two stray). Siswa melakukan presentasi kelompok dan ditanggapi oleh kelompok lain. Guru memberikan penghargaan bagi semua siswa yang telah berpartisipasi kegiatan pembelajaran

Kegiatan penutup dilakukan dengan cara siswa menyimpulkan materi pembelajaran dan memberikan refleksi. Guru menyampaikan informasi materi pertemuan berikut. Guru memberikan evaluasi (post test) dan dikerjakan oleh siswa. Guru menutup pelajaran dengan mengucapkan salam

Observasi dilakukan terhadap pelaksanaan pembelajaran dengan menggunakan lembar observasi guru dan siswa disertai catatan lapangan untuk mengamati setiap hal yang terjadi pada saat pelaksanaan pembelajaran dan mengamati aktivitas diskusi dengan menggunakan lembar observasi penilaian diskusi kelompok siswa. Kegiatan observasi dilakukan oleh peneliti dan dibantu oleh observer.

\section{Siklus II}

\section{Perencanaan Siklus II}

Pada siklus II tahapan perencanaan hampir sama dengan siklus I yaitu dengan menyusun RPP dengan materi sistem sirkulasi/mekanisme peredaran darah dan gangguan atau kelainan sistem peredaran darah. Menyiapkan ringkasan materi yang akan diajarkan yang dituangkan dalam media powerpoint, menyiapkan LKS, video pembelajaran, menyusun soal tes siklus II. Menyiapkan lembar observasi guru dan siswa dalam pelaksanaan pembelajaran disertai format lembar catatan lapangan untuk mengamati situasi ketika pembelajaran sedang berlangsung dan mencatat hal-hal yang belum terekam pada lembar observasi dan menyiapkan lembar observasi penilaian diskusi kelompok.

2. Pelaksanaan dan Observasi Siklus II

Pelaksanaan dilakukan dengan cara pendahuluan yaitu, guru memberi salam, absensi dan mengkondisikan kelas. Guru menanyakan kepada siswa materi pertemuan sebelumnya. Guru memotivasi dengan menunjukkan video pembelajaran, kemudian memberi kesempatan kepada siswa untuk memberikan pemahaman tentang gambar/video tersebut. Guru menyampaikan tujuan pembelajaran, gamabaran umum materi, dan penilaian.

Inti kegiatan dilakukan dengan guru membentuk siswa menjadi 8 kelompok yang heterogen dan membagikan LKPD di setiap kelompok. Guru menjelaskan cara mengerjakan LKPD dan menjelaskan langkah-langkah pembelajaran two stay two stray dan menyuruh siswa untuk mencermati persoalan di LKPD sebelum diskusi. Guru membimbing siswa mengumpulkan data dan informasi dalam kelompok dari kajian literatur. Guru membimbing siswa dalam diskusi untuk menyelesaikan pertanyaan dalam LKPD dan membuat media presentasi berupa bagan/charta pada kertas manila yang disiapkan. Guru mengarahkan dan membimbing kelompok untuk saling bertamu. Dua orang dari tiap kelompok berkunjung ke kelompok lain dan dua orang menerima tamu dari kelompok lain 
untuk bertukar informasi, setelah itu masing-masing kembali ke kelompok dan membagikan hasil temuan mereka kepada kelompok asalnya dan membahas hasil kerja mereka (menerapkan two stay two stray). Siswa melakukan presentasi hasil diskusi kelompok dan ditanggapi oleh kelompok lain. Guru memberikan penghargaan bagi semua siswa yang telah berpartisipasi kegiatan pembelajaran.

Penutup kegiatan pada siklus II dilakukan dengan siswa menyimpulkan materi pembelajaran dan memberikan refleksi. Guru menyampaikan informasi kepada siswa untuk persiapan praktikum pada pertemuan berikut. Guru memberikan evaluasi (post test) dan dikerjakan oleh siswa. Guru menutup pelajaran dengan mengucapkan salam.

Observasi dilakukan terhadap pelaksanaan pembelajaran dengan menggunakan lembar observasi guru dan siswa disertai catatan lapangan untuk mengamati setiap hal yang terjadi pada saat pelaksanaan pembelajaran dan mengamati aktivitas diskusi dengan menggunakan lembar observasi penilaian diskusi kelompok siswa. Kegiatan observasi dilakukan oleh peneliti dan dibantu oleh observer.

Pada akhir siklus data penelitian yang didapatkan dianalisis menggunakan teknik analisis kualitatif berupa catatan lapangan yang disajikan secara rinci dan lengkap selama proses penelitian berlangsung dan analisis kuantitatif sederhana digunakan untuk mengolah hasil belajar siswa yang diperoleh dari tes formatif. Kuantitatif sederhana yang digunakan berupa perhitungan nilai rata-rata, nilai tertinggi, nilai terendah dan jumlah siswa yang mencapai batas ketuntasan. Data hasil tes digunakan untuk menghitung ketuntasan belajar peserta didik dan ketuntasan kelas dengan menggunakan rumus (Tampubolon, 2014):

1) Ketuntasan peserta didik

2) Ketuntasan kelas

$$
\left(X_{1}\right)=\frac{\text { jumlah skor yang diperoleh }}{\text { skor maksimum }} X 100 \%
$$

$$
\left(X_{2}\right)=\frac{\text { jumlah siswa yang tuntas }}{\text { jumlah siswa seluruhnya }} \times 100 \%
$$

\section{HASIL DAN PEMBAHASAN \\ Refleksi Siklus I}

Proses pembelajaran dengan menerapkan model Cooperative learning tipe two stay two stray digunakan untuk siswa SMA kelas XI IPA 5 dapat menghidupkan suasana belajar namun belum maksimal meningkatkan aktivitas dan hasil belajar siswa.

\section{Hasil Belajar Siklus I}

Nilai siswa setelah dilaksanakannya post test pada siklus I digambarkan dalam Tabel 1.

Tabel 1. Persentase hasil belajar pada ranah kognitif siklus I

\begin{tabular}{cccccc}
\hline \multirow{2}{*}{ Siklus } & Test & \multicolumn{4}{c}{ Nilai } \\
\cline { 3 - 6 } & & \multicolumn{1}{c}{$\begin{array}{c}\text { Ketuntasan } \\
\text { Belajar }\end{array}$} & $\begin{array}{c}\text { Jumlah } \\
\text { Siswa }\end{array}$ & $\begin{array}{c}\text { Persentase } \\
\text { Ketuntasan (\%) }\end{array}$ & $\begin{array}{c}\text { Persentase rata- } \\
\text { rata (\%) }\end{array}$ \\
\hline \multirow{2}{*}{ I } & Post & Tuntas & 23 & 71,87 & 78,75 \\
& test & Tidak Tuntas & 9 & 28,12 & \\
\hline
\end{tabular}

Hasil ini menunjukkan bahwa terdapat 23 orang berhasil mencapai nilai di atas KKM dengan persentase ketuntasan sebesar $71,87 \%$ dan persentase rata-rata sebesar $78,75 \%$ pada post test siklus I. Persentase tersebut belum mencapai $80 \%$ 
sebagai target yang telah ditetapkan untuk dicapai. Karena itu perlu diadakan penelitian lanjutan pada siklus II.

\section{Hasil Penilaian Diskusi Siklus I}

Hasil penilaian diskusi siklus I dalam penerapan model cooperative learning tipe TSTS dapat digambarkan pada Tabel 2:

\section{Tabel 2. Hasil penilaian diskusi siklus I}

\begin{tabular}{cccccc}
\hline Siklus & $\begin{array}{c}\text { Aspek } \\
\text { Penilaian }\end{array}$ & $\begin{array}{c}\text { Skor total } \\
\text { tiap aspek }\end{array}$ & $\begin{array}{c}\text { Skor } \\
\text { maksimal } \\
\text { tiap aspek }\end{array}$ & $\begin{array}{c}\text { Rata-rata nilai } \\
\text { diskusi tiap } \\
\text { aspek }\end{array}$ & $\begin{array}{c}\text { Persentase rata- } \\
\text { rata nilai diskusi } \\
(\%)\end{array}$ \\
\hline \multirow{3}{*}{ I } & Keaktifan & 23 & 32 & 71,87 & \\
& Partisipasi & 25 & 32 & 78,12 & 75,00 \\
& Komunikasi & 24 & 32 & 75,00 & \\
\hline
\end{tabular}

Hasil ini menunjukkan bahwa pada siklus I persentase nilai diskusi siswa masih mendapatkan rata-rata nilai 75,00\%. Hal ini karena mereka belum terbiasa dengan metode two stay two stray dalam diskusi. Diskusi kelompok siswa yang diterapkan pada model Cooperative learning two stay two stray dikatakan baik dan berhasil jika nilai yang diperoleh mencapai 80. Karena nilai pada siklus I hanya $75,00 \%$ maka perlu diadakan siklus II.

\section{Hasil Observasi Aktivitas Guru dan Siswa Siklus I}

Hasil observasi menunjukkan bahwa pelaksanaan pembelajaran sudah benar dan sesuai dengan langkah-langkah pembelajaran dan rancangan pembelajaran. Terdapat beberapa kendala yang menjadi cacatan lapangan khususnya pada siklus I oleh masing-masing observer. Hal-hal yang menjadi catatan yaitu, (1) Manajemen waktu pada awal dan langkah kegiatan pembelajaran masih kurang optimal. Hal Ini terjadi karena pada waktu awal kegiatan pembelajaran terpotong oleh kegiatan lain yang menyebabkan siswa masih berada di luar kelas saat jam pelajaran sudah mulai. (2) Guru kurang maksimal dalam memberikan penguatan dan motivasi terhadap siswa sehingga ada siswa yang kurang antusias. (3) Pada saat berdiskusi menggunakan TSTS guru belum sepenuhnya melakukan bimbingan dan pengawasan terhadap seluruh siswa. Hal ini dilihat pada saat melakukan diskusi masih terdapat kelompok yang terlambat dalam memperoleh informasi dari kelompok lain karena siswa bercerita bukan tentang pelajaran. (4) Terdapat siswa yang kurang semangat dalam kegiatan pembelajaran. Hal ini diduga merupakan dampak dari rasa lapar atau aktifitas lain sebelumnya, sehingga terdapat satu siswa dalam satu kelompok masih mengantuk dan kurang fokus dalam menerima pembelajaran. Kendala yang ditemukan pada siklus I ini menjadi bahan refleksi untuk tindak lanjut pada siklus II.

Sebagaimana dikemukakan Elisandra (2017), kendala yang ditemukan dalam proses pembelajaran karena masih banyak siswa yang masuk terlambat dan siswa belum menguasai langkah-langkah TSTS dengan baik. Hal ini tentu menyebabkan siswa sedikit gaduh dan menyita waktu diskusi pada saat pergantian kelompok.

\section{Temuan Penelitian Siklus I}

Hasil temuan penelitian selama pelaksanaan siklus I sebagai berikut:

a. Pembelajaran pada siklus I memiliki persentase ketuntasan $71,87 \%$ dan persentase rata-rata $78,75 \%$ dengan taraf keberhasilan baik tetapi persentase tersebut belum mencapai target yang telah dibuat yaitu sebesar $80 \%$. Artinya, 
penerapan model cooperative learning two stay two stray pada siklus I berlangsung dengan baik tetapi belum memenuhi target ketuntasan yaitu $80 \%$

b. Keseluruhan aktivitas siswa saat pembelajaran berlangsung dengan baik. Namun dari aspek keaktifan, partisipasi, komunikasi dan kerja sama siswa masih kurang, sehingga persentase hasil diskusinya hanya sebesar 75,00\%. Persentase tersebut masih belum mencapai target yang telah dibuat yaitu sebesar $80 \%$

c. Siswa terlihat antusias dengan pembelajaran yang diterapkan karena menyenangkan dan tercipta suasana saling bertukar informasi dengan sesama kelompok.

d. Hanya siswa yang aktif terlihat mendominasi dalam penerapan Cooperative learning two stay two stray.

\section{Refleksi Siklus II}

Proses pembelajaran dengan menerapkan model Cooperative learning tipe two stay two stray cocok digunakan untuk siswa SMA kelas XI IPA 5 karena dapat meningkatkan aktivitas dan hasil belajar siswa untuk berdiskusi bersama kelompoknya, saling bertukar pendapat dengan kelompok lain secara maksimal. Hal ini dilihat pada siklus 2 tidak ditemukan kendala seperti pada siklus 1 .

\section{Hasil Belajar Siklus II}

Nilai siswa setelah dilaksanakannya post test pada siklus II digambarkan dalam Tabel 3:

Tabel 3. Persentase hasil belajar pada ranah kognitif siklus siklus II

\begin{tabular}{|c|c|c|c|c|c|}
\hline \multirow[b]{2}{*}{ Siklus } & \multirow[b]{2}{*}{ Test } & \multicolumn{4}{|c|}{ Nilai } \\
\hline & & $\begin{array}{c}\text { Ketuntasan } \\
\text { Belajar }\end{array}$ & $\begin{array}{l}\text { Jumlah } \\
\text { Siswa }\end{array}$ & $\begin{array}{c}\text { Persentase } \\
\text { Ketuntasan }(\%)\end{array}$ & $\begin{array}{c}\text { Persentase rata-rata } \\
(\%)\end{array}$ \\
\hline II & $\begin{array}{l}\text { Post } \\
\text { test }\end{array}$ & $\begin{array}{l}\text { Tuntas } \\
\text { Tidak Tuntas }\end{array}$ & $\begin{array}{c}31 \\
1\end{array}$ & $\begin{array}{c}96,87 \\
3,12\end{array}$ & 96,87 \\
\hline
\end{tabular}

Hal ini menunjukkan pada post test siklus II, siswa yang berhasil mencapai nilai di atas KKM adalah 31 orang dengan persentase ketuntasan dan persentase rata-rata siswa sebesar $96,87 \%$. Artinya capaian nilai post test siklus II di atas KKM lebih baik dibandingkan dengan siklus I yaitu meningkat sebesar 25,00\%. Peningkatan hasil belajar pada siklus II ini tidak terlepas dari hasil evaluasi dan refleksi atas kelemahan pada tahapan pelaksanaan dan observasi pada siklus I. Pada tahapan pelaksanaan dan observasi siklus II peneliti dapat manajemen waktu dengan baik sehingga penerapan TSTS dapat meningkatkan hasil belajar pada aspek kognitif siswa. Dapat disimpulkan bahwa penerapan model Cooperative learning tipe two stay two stray dapat meningkatan hasil belajar siswa pada materi sistem sirkulasi kelas XI IPA 5 SMAN 8 Malang.

Kesesuaian perencanaan dengan pelaksanaan pembelajaran model pembelajaran kooperatif tipe two stay two stray yang baik dapat meningkatkan hasil belajar peserta didik karena lebih aktif dan termotivasi dalam belajar, percaya diri dan saling bekerja sama serta bertanggung jawab (Sahela \& Muhammadi, 2020). Pengaruh penggunaan model pembelajaran kooperatif tipe two stay two stray dengan pendekatan saintifik dalam pembelajaran dapat meningkatkan hasil belajar siswa (Gumay, 2017; Trisnawati, 2017).

\section{Hasil Penilaian Diskusi Siklus II}

Hasil penilaian diskusi siklus II dalam penerapan model cooperative learning tipe two stay two stray dapat digambarkan pada Tabel 4: 
Tabel 4. Hasil penilaian diskusi siklus II

\begin{tabular}{cccccc}
\hline Siklus & Aspek Penilaian & $\begin{array}{c}\text { Skor total } \\
\text { tiap aspek }\end{array}$ & $\begin{array}{c}\text { Skor } \\
\text { maksimal tiap } \\
\text { aspek }\end{array}$ & $\begin{array}{c}\text { Rata-rata nilai } \\
\text { diskusi tiap } \\
\text { aspek }\end{array}$ & $\begin{array}{c}\text { Persentase rata- } \\
\text { rata nilai diskusi } \\
(\%)\end{array}$ \\
\hline \multirow{4}{*}{ II } & Keaktifan & 26 & 32 & 81,25 & \\
& Partisipasi & 27 & 32 & 84,37 & 85,93 \\
& Komunikasi & 26 & 32 & 81,25 & \\
\hline
\end{tabular}

Hasilnya menunjukkan pada siklus II siswa sangat antusias dalam melaksanakan diskusi agar kelompok mereka mendapatkan nilai terbaik sehingga rata-rata nilai diskusi meningkat sebesar $10,93 \%$ yang semula $75,00 \%$ menjadi $85,93 \%$. Dapat disimpulkan bahwa kegiatan diskusi dengan two stay two stray yang dilakukan semakin menunjukkan peningkatan interaksi siswa baik dari aspek keaktifan, partisipasi, komunikasi dan kerjasama dalam kelompok maupun antar kelompok. Ini terjadi karena siswa sudah terbiasa dengan pembelajaran kooperatif two stay two stray sehingga antusias belajar mereka sangat tinggi untuk memperoleh informasi dari teman kelompon yang lain.

Menurut Djuramang (2018), penerapan model two stay two stray dalam proses pembelajaran dapat menuntut siswa untuk berani, aktif, percaya diri, dan bertanggung jawab sehingga stay two stray ini memberikan pengaruh terhadap keaktifan dan sangat diminati oleh peserta didik. Selanjutnya Elisandra (2017) menyatakan siswa dapat diarahkan untuk aktif, baik dalam berdiskusi, tanya jawab, mencari jawaban, menjelaskan dan juga menyimak materi yang dijelaskan oleh teman dengan menggunakan model pembelajaran kooperatif tipe TSTS.

\section{Hasil Observasi Aktivitas Guru dan Siswa Siklus II}

Pada siklus II, penerapan model Cooperative learning TSTS dalam kegiatan pembelajaran dapat menghidupkan suasana belajar untuk berdiskusi bersama kelompoknya dan saling bertukar pendapat dengan kelompok lain. Hal ini dilihat dari bimbingan dan pengawasan guru yang menyeluruh saat menerapkan model TSTS dalam kegiatan pembelajaran sehingga siswa terlihat tertib dan tidak mengobrol yang bukan tentang pelajaran dan hampir semua siswa sudah aktif.

Pada siklus II, solusi yang dilakukan oleh peneliti, yaitu: (a) memanfaatkan waktu dengan baik; (b) guru meningkatkan bimbingan dan pengawasan lebih terhadap seluruh siswa dalam melaksanakan tugas berdiskusi; (c) guru memberikan motivasi dan penguatan lebih maksimal agar siswa lebih aktif dan bersemangat dalam mengikuti pembelajaran. Ini menunjukkan guru sudah memahami dan menguasai langkah Cooperative learning two stay two stray yang lebih baik dibanding dengan siklus sebelumnya. Siswa menjadi lebih aktif bertukar informasi dengan kelompok lain, berani dan percaya diri, sehingga meningkatan persentase hasil belajar siswa pada siklus 2 .

Hal ini didukung Dumaini, Suarjana, dan Dibia (2019) proses pembelajaran dan aktivitas siswa yang dengan model pembelajaran kooperatif tipe TSTS membuat siswa lebih aktif dalam pembelajaran karena siswa harus bertamu ke kelompok lain untuk mencari informasi dan bagi siswa yang diam dalam kelompok harus berbagi informasi kepada kelompok lain yang bertamu. Kegiatan bertamu ini membentuk timbal balik dan komunikasi positif antar siswa dan menjadikan siswa setiap kelompok mendapat tanggung jawab dalam menyelesaikan tugas bertamu dan menerima tamu dengan baik. Setiap siswa dituntut bertanggung jawab dalam bertamu dan menerima tamu sehingga mereka akan melalaikan dan mengabaikan tugasnya. Selanjutnya Kumape (2015) 
mengatakan penerapan pembelajaran TSTS berpengaruh signifikan terhadap aktivitas dan hasil belajar siswa di mana siswa yang belajar dengan model TSTS memiliki aktivitas yang lebih baik karena siswa memiliki rasa percaya diri, dapat bekerja sama dan menuntut siswa agar terus aktif, inovatif dan berjiwa sosial.

\section{Temuan Penelitian Siklus II}

Hasil temuan penelitian selama pelaksanaan siklus II sebagai berikut:

a. Pembelajaran pada siklus II memiliki persentase $96,87 \%$ dengan taraf keberhasilan sangat baik karena sudah mencapai target yang telah dibuat yaitu sebesar $80 \%$. Artinya pada siklus II, penerapan model cooperative learning two stay two stray berlangsung dengan sangat baik sehingga dapat memenuhi ketuntasan hasil belajar kelas.

b. Keseluruhan aktivitas siswa saat pembelajaran, berlangsung dengan baik. Baik aspek keaktifan, partisipasi, komunikasi maupun kerja sama meningkat menjadi $85,93 \%$. Persentase tersebut telah melampaui target yang telah dibuat yaitu sebesar $80 \%$.

c. Siswa sangat antusias dengan model pembelajaran yang diterapkan karena menyenangkan dan tercipta suasana saling bertukar pendapat atau berbagi informasi tidak hanya dalam kelompok tetapi dengan sesama kelompok.

d. Dalam menerapakan cooperative learning two stay two stray sudah didominasi pada semua siswa sehingga terjadi peningkatan hasil belajar dengan tingkat ketuntasan mencapai $85,93 \%$.

Berdasarkan tabel persentase ketuntasan belajar siswa dan rata-rata penilaian diskusi, dapat dibuat pada Gambar 1 persentase rata-rata ketuntasan belajar siswa dan rata-rata penilaian diskusi:

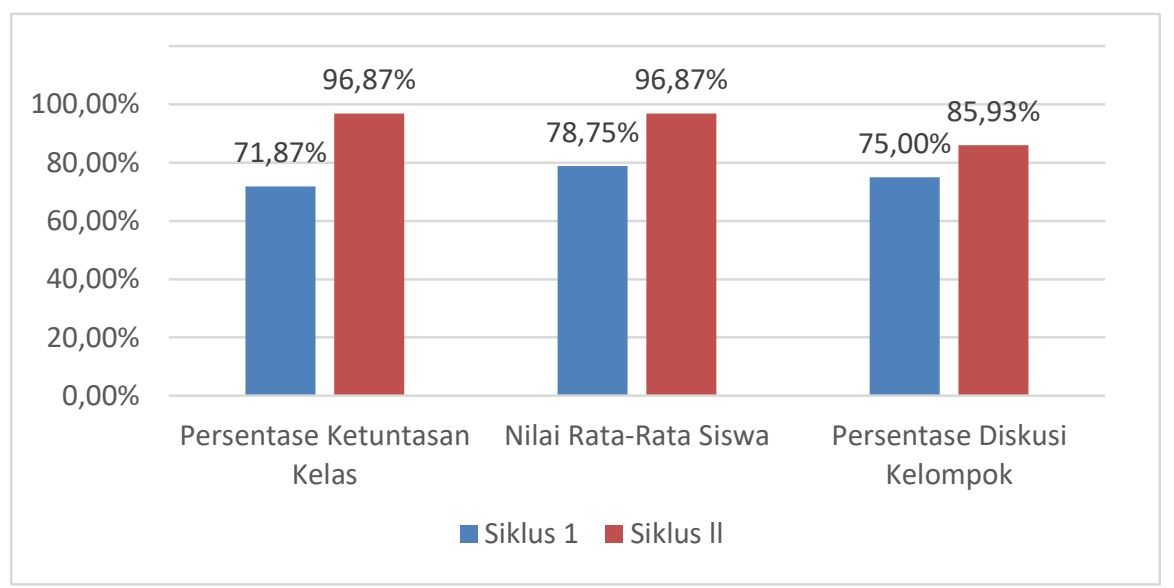

\section{Gambar 1. Grafik persentase rata-rata ketuntasan hasil belajar siswa}

Gambar ini menunjukkan peningkatan persentase antara siklus I dan siklus II tentang persentase ketuntasan kelas, nilai rata-rata siswa dan keaktifan diskusi kelompok. Persentase ketuntasan kelas mengalami peningkatan 25\%. Persentase nilai rata-rata siswa mengalami peningkatan sebesar $18,12 \%$ dan persentase ratarata nilai diskusi kelompok mengalami peningkatan sebesar 10,93\%. Artinya pada siklus II guru dan peserta didik melaksanakan langkah-langkah pada siklus II sesuai perencanaan pembelajaran dengan baik. Peningkatan rata-rata nilai pada siklus kedua juga merupakan hasil refleksi dan evaluasi guru dari siklus pertama. Kesesuaian rencana dan pelaksanaan pembelajaran ini membentuk pola interaksi sosial belajar antara siswa dengan siswa dan siswa dengan guru sehingga dapat 
meningkatkan hasil belajar siswa. Karena itu, disimpulkan bahwa hasil belajar siswa semakin baik dan berkualitas apabila proses pembelajaran menggunakan pembelajaran kooperatif two stay two stray.

Menurut Habibi \& Rusimamto (2014) siswa memiliki respon belajar yang tinggi terhadap model pembelajaran kooperatif tipe two stay two stray sehingga dapat meningkatkan hasil belajar siswa. Hasnidar, Sulihin, dan Elihami (2020) menyatakan proses belajar menggunakan two stay two stray dapat meningkatkan motivasi belajar, membentuk interaksi pembelajaran siswa dengan guru, dan dapat mengubah emosional dan perilaku hidup siswa hidup menjadi lebih berkualitas baik jasmani maupun rohani dalam bidang pendidikan.

\section{SIMPULAN}

Kesimpulan dari Penelitian ini adalah, model Cooperative learning two stay two stray dapat meningkatkan hasil belajar siswa pada materi sistem sirkulasi Kelas XI IPA 5 SMAN 8 Malang, dengan peningkatan dari siklus I ke siklus II tentang persentase ketuntasan kelas sebesar $25 \%$, peningkatan persentase nilai rata-rata siswa sebesar $18,12 \%$ dan persentase rata-rata nilai diskusi kelompok sebesar $10,93 \%$.

Saran dalam penelitian ini adalah perlu adanya pengelolaan kelas dan pengaturan waktu yang tepat agar seluruh kegiatan pembelajaran dapat berjalan dengan baik. Saran untuk peneliti selanjutnya yaitu, agar bisa melaksanakan penelitian menggunakan model Cooperative learning two stay two stray dengan subjek dan objek penelitian yang berbeda agar dapat meningkatkan kevalidan data.

\section{DAFTAR PUSTAKA}

Arthaningsih, N. K. J., \& Diputra, K. S. (2019). Pengaruh model pembelajaran kooperatif tipe two stay two stray melalui lesson study terhadap hasil belajar matematika. Journal of Education Technology, 2(4), 128-136. Retrieved from https://ejournal.undiksha.ac.id/index.php/JET/article/view/16424

Djuramang, R. R. (2018). Pengaruh model pembelajaran kooperatif tipe two stay twp stray dan tipe giving question and getting answer terhadap keaktifan dan hasil belajar siswa pada materi sistem ekskresi. Jurnal Pendidikan Glasser, 2(1). doi: https://doi.org/0.32529/glasser.v3i1.81

Dumaini, N. K. D., Suarjana, I. M., \& Dibia, I. K. (2019). Pengaruh model pembelajaran two stay two stray terhadap hasil belajar IPA. Journal of Education Technology, 3(2), 103-110. Retrieved from https://ejournal.undiksha.ac.id/index.php/JJPGSD/article/view/3763

Elisandra, F. (2017). Penerapan model pembelajaran kooperatif tipe two stay two stray dengan media poster untuk meningkatkan hasil belajar siswa pada materi pemanasan global. Inovasi Pendidikan Fisika, 6(3). Retrieved from https://jurnalmahasiswa.unesa.ac.id/index.php/inovasi-pendidikanfisika/article/view/20205

Gayatri, E. R. P., Bahar, A., \& Handayani, D. (2017). Perbandingan penerapan model pembelajaran learning cycle (5e) dan two stay two stray. Alotrop, l(1).

Gumay, O. P. U. (2017). Pengaruh model pembelajaran kooperatif tipe two stay two stray terhadap hasil belajar fisika siswa Kelas 8 SMP Negeri 3 Lubuklinggau. SPEJ (Science and Physic Education Journal), 1(1), 49-58. 
doi: https://doi.org/10.31539/spej.v1i1.102

Habibi, Z., \& Rusimamto, P. W. (2014). Pengaruh model pembelajaran kooperatif tipe tsts (two stay two stray) terhadap hasil belajar siswa pada mata pelajaran teknik elektronika dasar di SMKN 1 Jetis Mojokerto. Jurnal Pendidikan Teknik Elektro, 3(3). from https://jurnalmahasiswa.unesa.ac.id/index.php/jurnal-pendidikan-teknikelektro/article/view/10122

Hasnidar, H., Sulihin, S., \& Elihami, E. (2020). Developing of multiple intelligences in students with the two stay two strays type. Edumaspul: Jurnal Pendidikan, 4(2), 7-12. Retrieved from https://ummaspul.ejournal.id/maspuljr/article/view/680

Hidayat, T. M., \& Muhson, A. (2018). The impact of think pair share and two stay two stray learning model towards learning outcomes and cooperation ability. Dinamika Pendidikan, 13(1), 119-129. Retrieved from https://journal.unnes.ac.id/nju/index.php/DP/article/view/15045

Huda, S., Yasin, M., Fitri, A., Syazali, M., Supriadi, N., Umam, R., \& Jermsittiparsert, K. (2020). Numerical ability analysis: The impact of the two stay-two stray learning model on the sequence and series topic in Islamic Boarding School. In Journal of Physics: Conference Series (Vol. 1467, pp. 1-10). Retrieved from https://www.researchgate.net/publication/340224351

Kumape, S. (2015). Pengaruh penerapan model pembelajaran kooperatif tipe two stay two stray terhadap aktivitas dan hasil belajar siswa tentang IPA di Kelas VI SD Inpres Palupi. Jurnal Kreatif Online, 4(4). Retrieved from http://jurnal.untad.ac.id/jurnal/index.php/JKTO/article/view/6131

Kusumaningrum, R., Budiyono, B., \& Subanti, S. (2015). Eksperimentasi model pembelajaran kooperatif tipe two stay two stray (TSTS), numbered heads together (NHT), dan think pair share (TPS) pada materi lingkaran ditinjau dari kreativitas belajar matematika siswa SMP Negeri di Kabupaten Sukoharjo. Jurnal Pembelajaran Matematika, 3(7). Retrieved from https://www.neliti.com/id/publications/122847/eksperimentasi-modelpembelajaran-kooperatif-tipe-two-stay-two-stray-tsts-number

Lubis, M. A. (2018). Pengaruh model pembelajaran kooperatif tipe two stay two stray (tsts) dan artikulasi terhadap hasil belajar siswa pada materi ekosistem di SMA Negeri 1 Sibabangun Kabupaten Tapanuli Tengah. Jurnal Biolokus, 1(2), 117-122. Retrieved from http://jurnaltarbiyah.uinsu.ac.id/index.php/biolokus/article/view/352

Paembonan, P. (2019). Peningkatan aktivitas dan hasil belajar matematika melalui penerapan model kooperatif tipe two stay two stray dengan pendekatan problem posing pada siswa kelas VII SMP Negeri 1 Rantepao. Jurnal Pemikiran Dan Pengembangan Pembelajaran, 1(2), 104-113. Retrieved from http://www.ejournal-jp3.com/index.php/Pendidikan/article/view/53

Rhiantini, S., Sunarya, D. T., \& Iswara, P. D. (2017). Penerapan metode two stay two stray dalam upaya meningkatkan keterampilan menulis pada materi laporan pengamatan. Jurnal Pena Ilmiah, 2(1), 121-130. Retrieved from https://ejournal.upi.edu/index.php/penailmiah/article/view/9533

Sahela, T., \& Muhammadi, M. (2020). Pembelajaran tematik terpadu menggunakan model cooperative learning tipe two stay two stray kelas IV SD. Jurnal Pendidikan Tambusai, 4(2), 1437-1450. Retrieved from https://jptam.org/index.php/jptam/article/view/609 
Sari, A., \& Azmi, M. P. (2018). Penerapan model kooperatif tipe two stay two stray (TSTS) terhadap kemampuan komunikasi matematis. Jurnal Cendekia: Jurnal Pendidikan Matematika, 2(1), 164-171. Retrieved from http://ejournal.uin-suska.ac.id/index.php/SJME/article/view/4043

Tampubolon, S. (2014). Penelitian tindakan kelas sebagai pengembangan profesi pendidik dan keilmuan. Jakarta: Erlangga. Retrieved from http://kin.perpusnas.go.id/DisplayData.aspx?pId=29226\&pRegionCode=UNI KAMA\&pClientId=717

Trisnawati, N. F. (2017). Efektivitas model pembelajaran kooperatif tipe two stay two stray dengan pendekatan saintifik dalam pembelajaran matematika pada siswa SMP Negeri 2 Kota Sorong. Median: Jurnal Ilmu Ilmu Eksakta, 9(3), 36-42. Retrieved from https://ejournal.umsorong.ac.id/index.php/median/article/view/15

Wisarja, I. K., \& Sudarsana, I. K. (2017). Refleksi kritis ideologi pendidikan konservatisme dan liberalisme menuju paradiga baru pendidikan. Journal of Education Research and Evaluation, 1(4), 283. https://doi.org/10.23887/jere.v1i4.11925

Yulianti, R., Muntari, M., \& Haris, M. (2015). Pengaruh model pembelajaran kooperatif tipe two stay two stray (tsts) dengan pendekatan brain-based learning terhadap hasil belajar kimia materi pokok struktur atom dan sistem periodik unsur pada siswa kelas x sman 1 kediri. Jurnal Pijar MIPA, 10(1). Retrieved from http://jurnalfkip.unram.ac.id/index.php/JPM/article/view/19

Yusri, Y., Mantasiah, R., \& Jufri, J. (2018). The use of two stay two stray model in english teaching to increase student's learning outcome. Journal of Advanced English Studies, 1(1), 39-43. Retrieved from https://sastra.unifa.ac.id/journal/index.php/jes/article/view/12 